\title{
Effects of Pricing Influences and Selling Characteristics on Plant Sales in the Green Industry
}

\author{
Benjamin L. Campbell ${ }^{\mathbf{1}}$ \\ Vineland Research and Innovation Centre, 4890 Victoria Avenue North, P.O. \\ Box 4000, Vineland Station, Ontario, Canada LOR 2E0
}

\author{
Charles R. Hall \\ Department of Horticulture, Texas A\&M University, 202 Horticulture/Forest \\ Science Building, 2133 TAMU, College Station, TX 77843-2124
}

Additional index words. green industry, pricing, sales impacts, marketing, economics

\begin{abstract}
Data from the 2004 National Nursery Survey conducted by the USDA-CSREES S-1021 Multistate Research Committee (referred to as the Green Industry Research Consortium) were used to evaluate the effect of pricing influences and selling characteristics on total gross firm sales and gross sales of several plant categories (trees, roses, shrubs/azaleas, herbaceous perennials, bedding plants, foliage, and potted flowering plants) for commercial nurseries and greenhouses. As expected, the firm's selling characteristics play a large role in whether a firm sells a specific plant category. Demand factors also play a role in affecting plant category sales with income, population, and race tending to be the only significant variables, except for the potted flowering plants category. In regard to sales, our results show that certain factors affecting pricing decisions play a critical role in both plant category sales and total sales. Furthermore, demand and business characteristics play a limited role as well, but not as big a role as selling characteristics. Of note is that firms with an increased percentage of sales through wholesale channels (of most plant categories and overall) result in increased sales. By understanding the nursery and greenhouse industry environment and how decisions affect overall and categorical sales, firms can implement strategies that capitalize on factors that have the potential to generate increased sales.
\end{abstract}

The U.S. nursery and greenhouse industry (often referred to as the Green Industry) had $\approx \$ 16.8$ billion in total grower cash receipts during 2005 (Jerardo, 2007). Although the Green Industry is a multibillion dollar industry that is still expanding (albeit at a slower rate), U.S. nursery and greenhouse owner/operators face numerous challenges in their struggle to have and/or maintain a successful business. Given that the industry is maturing (Hall, 2007), the competitive rivalry among firms is intensifying. With the increased competition that comes along with slower growth, firms compete by finding alternative markets or through capturing market share from other firms. Firms failing to adapt and implement new strategies during the transition from a rapidly growing to a mature market will face problems most likely resulting in their elimination from the marketplace.

Given the transition from a rapidly growing to a mature market, owner/operators should be taking an in-depth look at their business practices and determining if there are ways to increase sales and profitability. Increased sales may often come as a result of subtle changes in pricing behavior and vice

Received for publication 22 Sept. 2009. Accepted for publication $4 \mathrm{Jan} .2010$.

${ }^{1}$ To whom reprint requests should be addressed; e-mail chall@ag.tamu.edu. versa. For instance, an operator that uses last year's prices as an important indicator of how to price this year may fail to incorporate key information regarding the present market conditions, thereby potentially lowering sales.

Recent research has addressed changes associated with marketing practices within the Green Industry. Behe et al. (2008) found that regional differences among nursery growers exist in various marketing practices, including sales management, selling practices, pricing, and advertising, whereas Hodges et al. (2008) found regional differences in various nursery production practices, including temporary labor force levels, growing systems, contracting, and use of integrated pest management systems. Campbell et al. (2009) compared industry practices in 1988 versus 2003 and found numerous changes have occurred in production, marketing, and advertising practices with some regions experiencing more structural change than others. Yue and Behe (2008) found that the purchase of specific plant products affects consumer choice of outlet. Finally, Andrade and Hinson (2009) evaluated factors affecting choice of rewholesalers and other nursery marketing channels and found that diversified growers, in regard to their marketing strategies, were more likely to use a mass merchandiser and garden center channel and that plant group also affected the choice of mass merchandiser and landscaper channels.
Based on the varying practices noted within previous research, our objective was to evaluate the effect of pricing influences (i.e., cost of production, other grower prices, plant quality, market demand, product uniqueness, product inventory, and last year's prices) and selling characteristics (e.g., total advertising, tradeshow attendance, and percentage of: repeat customers, negotiated sales, native plant sales, wholesale sales, exports, and precommitted sales) on total gross firm sales as well as gross sales associated with several plant categories (trees, roses, shrubs and azaleas, herbaceous perennials, bedding plants, foliage, and potted flowering plants) for commercial nurseries and greenhouses. By understanding the effects of pricing influences and selling characteristics, we can identify which factors play the largest role in increasing/decreasing sales, thereby offering valuable insights to commercial nursery and greenhouse owner/operators. To control for other factors that may contribute to a firm's sales, we use other variables associated with business characteristics and local demand factors as control variables. By understanding the impacts of pricing and selling characteristics, owner/operators will be able to better evaluate their business-specific practices and more accurately determine where changes can be made to increase sales.

\section{Materials and Methods}

Data from the 2004 National Nursery Survey (NNS04), conducted by the USDACSREES Multistate Research Committee S-1021 (referred to as the Green Industry Research Consortium), were used as the primary data source for this study. The survey used a standard sampling methodology with surveys being sent to nursery and greenhouse firms in 44 states representing $93 \%$ of total grower cash receipts (Brooker et al., 2005). An in-depth discussion of the survey procedures and descriptive statistics for each question along with a copy of the survey instrument can be found in Brooker et al. (2005).

The national survey resulted in a total of 2485 surveys being returned; however, given the nature of the survey in relation to how responding firms were asked to detail gross sales, only 460 completed surveys were available that provided total gross sales in dollars with the rest of the surveys using the alternately available categorical number scale to define their sales. The categorical scale had 11 gross sales categories, but the categories could not be linked back to an actual dollar amount, thereby causing problems for any regressionbased analysis in which sales are the dependent variable. Furthermore, given that the purpose of this article was to examine commercial (as opposed to hobby farms) operations, we adopted the USDA definition, as described by Andrade and Hinson (2009), in which a commercial firm has total gross sales equal to or in excess of $\$ 10,000$. After eliminating incomplete surveys and noncommercial firms, a total of 342 firms met our 
requirements. To determine if any bias was present between our final sample and the "left out" firms, we used a two-sample $t$ test to compare the demographics of each group. Our findings indicate that there was very little difference between the mean values for the characteristics with export levels being the lone exception. It should be noted that the "left out" sample could not be broken down into commercial firms only given sale levels were either left out entirely or categorized into sales levels above the $\$ 10,000$ USDA cutoff.

The objective of this article was to identify which factors influence both total gross sales and gross plant category sales. Plant categories included trees (deciduous shade and flowering trees; evergreens, but not including Christmas trees; and tree fruits), roses, shrubs/azaleas (deciduous shrubs, narrow-leaved evergreen shrubs, broad-leaved evergreen shrubs, and azaleas), herbaceous perennials, bedding plants (flowering annuals and vegetables, fruits, and herbs), foliage, and potted flowering plants. Summary statistics of total gross sales and gross plant category sales can be found in Table 1 . As expected, although not all firms sold every type of plant category, some firms did sell numerous plant categories.

Using previous research, explanatory variables were identified and divided into groups. These groups consisted of pricing influences, demand factors, business characteristics, and selling characteristics. Variable definitions and descriptive statistics can be found in Tables 2 and 3, respectively. Demand characteristics were not specifically collected in the national survey but were deemed important given the findings of Dennis and Behe (2007), notably that certain demographics (e.g., age and ethnicity) influence plant purchases. However, zip codes were collected that allowed area characteristics to be matched with each firm. Zip codes were linked to counties using the SAS software (Statistical Analysis System Version 9.1; SAS Institute, Inc., Cary, NC) macro "sashelp.zipcode." Zip codes and counties were then linked to the 2003 USDA county census estimates for the demand factors (e.g., population, average population growth, median household income, race, same household, and urbanicity).

The county-level data could not be broken down into more compact areas. Because such county-level demand characteristics may not $100 \%$ correlate with the situation faced by each nursery, however, county-level characteristics were believed to encompass a majority of retail consumers for a grower-retailer firm. As indicated by Hall (2002), consumers generally only travel a short distance to either their primary $(91.1 \%$ travel less than 6 miles $)$ or secondary ( $83.9 \%$ travel less than 6 miles) garden center. Given the findings of Hall (2002), county-level data serve as a close proxy, especially with regard to identifying consumers that have a higher probability of shopping at a grower/retailer.

Data analysis. The nature of the data entails two different types of analysis: 1) for total gross sales and 2) sales for individual plant categories. Total gross sales lends itself to simple ordinary least squares regression; however, diagnostics for collinearity and influential observations (i.e., DFITS, R-student, and Cook's D statistics) indicated low levels of collinearity but the presence of several influential observations. Failure to account for influential observations may result in estimates that are a direct result of only a few observations implying that deleting or giving a lower weight to those observations will result in drastically different results (Davidson and MacKinnon, 1993). To account for these influential observations, a robust regression procedure was used. We also transformed the model into a semilog form:

$$
\begin{aligned}
\ln T S_{i}= & \sum_{j}^{n} P I_{i j} \beta_{j}+\sum_{k}^{m} D F_{i k} \beta_{k} \\
& +\sum_{r}^{p} B C_{i r} \beta_{r}+\sum_{s}^{t} S C_{i s} \beta_{s}+\varepsilon_{i}
\end{aligned}
$$

where TS represents the gross total sales of the $i^{\text {th }}$ firm, PI represents the $i^{\text {th }}$ firm's $j^{\text {th }}$ pricing influence, DF represents the $i^{\text {th }}$ firm's $\mathrm{k}^{\text {th }}$ demand factor, $\mathrm{BC}$ represents the $\mathrm{i}^{\text {th }}$ firm's $\mathrm{r}^{\text {th }}$ business characteristic, and SC represents the $i^{\text {th }}$ firm's $\mathrm{s}^{\text {th }}$ selling characteristic.

The analyses for the plant category models were somewhat different from that of total gross sales. Unlike total gross sales, each plant category may suffer from self-selection. Examination of Table 1 indicates a large number of firms do not sell certain plant categories. For instance, only $14.6 \%$ of the firms sold roses, implying $85.4 \%$ had rose sales equal to $\$ 0$. Failure to adequately account for selfselection could lead to results being both biased and inconsistent (Byrne et al., 1998).

Table 1. Summary statistics of sales per firm by plant category for data collected as part of the National Nursery Survey conducted by the Green Industry Research Consortium.

\begin{tabular}{lccr}
\hline Category & $\begin{array}{c}\text { Percent of } \\
\text { observations }\end{array}$ & $\begin{array}{c}\text { Avg sales } \\
\text { per firm }(\$)\end{array}$ & $\begin{array}{c}\text { SD per } \\
\text { firm }(\$)\end{array}$ \\
\hline Total & 100.0 & 759,433 & $2,639,913$ \\
Trees & 51.8 & 33,992 & 158,597 \\
Roses & 14.6 & 44,081 & 196,422 \\
Shrubs + azaleas & 42.1 & 44,081 & 175,057 \\
Herbaceous perennials & 31.9 & 87,014 & 247,442 \\
Bedding plants & 26.6 & 139,141 & 281,412 \\
Foliage & 14.6 & 235,025 & 642,758 \\
Flowering pots & 16.1 & 58,117 & 106,024 \\
\hline
\end{tabular}

${ }^{2}$ The sum of the percent observations does not add to $100 \%$ because most firms sell several plant categories. ${ }^{\mathrm{y}}$ Degree of censoring for each plant category is $100 \%$ observations, in which censoring can be thought of as the number of firms with $\$ 0$ sales in a plant category.

Taking the notation as provided in Greene (2003), self-selection can be described as follows:

Self-selection equation : $\mathrm{z}_{\mathrm{i}}^{*}=\mathrm{w}_{\mathrm{i}}{ }^{\prime} \gamma+\mu_{\mathrm{i}}$

and

$$
\text { Sales equation : } y_{i}=x_{i}{ }^{\prime} \beta+\varepsilon_{\mathrm{i}}
$$

where $y_{i}$ is observed only when $z_{i}^{*}>0$. In our case, $y_{i}$ can be thought of as a vector of plant category sales, which is a function of an $\mathrm{n} \times \mathrm{m}$ matrix of explanatory variables times a vector of coefficients plus an error term, whereas $\mathrm{z}_{\mathrm{i}}{ }^{*}$ is a selection variable that is a function of a $\mathrm{k} \times \mathrm{j}$ matrix of explanatory variables that determines $\mathrm{z}_{\mathrm{i}}^{*}$. Given the selection variable, $\mathrm{z}_{\mathrm{i}}{ }^{*}$, is unobserved in magnitude for our case, we modify Eqs. 2 and 3 as described by Greene (2003) so that

$$
\begin{aligned}
& z_{i}^{*}=w_{i}{ }^{\prime} \gamma+\mu_{\mathrm{i}}, z_{i}=1 \text { if } z_{i}{ }^{*}>0 \text { and } \\
& z_{i}=0 \text { otherwise }
\end{aligned}
$$

where $\operatorname{Prob}\left(z_{i}=1 \mid w_{i}\right)=\Phi\left(w_{i}{ }^{\prime} \gamma\right)$ and

$$
\operatorname{Prob}\left(z_{i}=0 \mid w_{i}\right)=1-\Phi\left(w_{i}^{\prime} \gamma\right) \text {, and }
$$$$
y_{i}=x_{i}{ }^{\prime} \beta+\varepsilon_{i} \text {, observed if } z_{i}=1
$$

Eqs. 4 and 5 can then be estimated using the two-step procedure proposed by Heckman (1979) in which Eq. 4, the "participation" equation, is estimated through maximum likelihood in the form of a bivariate probit model and Eq. 5, the "sales" equation, is estimated through regression. In the "participation" decision, a firm decides whether to sell a plant category and is modeled as a binary probit with participation/no participation as the dependent variable. Explanatory variables were the same as those in Tables 2 and 3 with the exception that pricing influences were replaced by factors impacting the business (i.e., land, market demand, labor, managerial experience, competition, and environmental regulations). From the probit model, we obtain the Inverse Mill's Ratio (IMR). The IMR is calculated as $\phi\left(\mathrm{w}_{\mathrm{i}}{ }^{\prime} \hat{\mathrm{y}}\right) / \Phi\left(\mathrm{w}_{\mathrm{i}}{ }^{\prime} \hat{\mathrm{y}}\right)$, in which $\phi()$ is the probability density function of the standard normal distribution and $\Phi()$ is the cumulative distribution function of the standard normal distribution (Greene, 2003).

The second step, "sales" decision, is generally modeled through ordinary least squares; however, diagnostic tests revealed several influential observations. A robust regression was used to alleviate the large effects associated with the influential observations. Like with the total gross sales model, we used a semilog structure that takes the same form as Eq. 1, but the plant category sales were substituted for total gross sales, denoted by PC in Eq. 6, and the IMR is added as an additional regressor in the model to account for selection bias.

$$
\begin{aligned}
\ln P C_{i}= & \sum_{j}^{n} \beta_{j} P I_{j i}+\sum_{k}^{m} \beta_{k} D F_{k i} \\
& +\sum_{r}^{p} \beta_{r} B C_{r i}+\sum_{s}^{t} \beta_{s} S C_{s i} \\
& +\beta_{i} I M R_{t}+\varepsilon_{i}
\end{aligned}
$$

Only observations in which $\mathrm{y}_{\mathrm{i}}>0$ are used in the estimation of Eq. 6. In regard to any 
Table 2. Definitions associated with each of the explanatory variables included in regression models developed to analyze data from the National Nursery Survey conducted by the Green Industry Research Consortium.

Variable
Business influences ${ }^{\mathrm{y}, \mathrm{x}}$
Market demand
Labor
Managerial experience
Competition
Environmental regulations
Pricing influences
Cost of production
Other grower prices
Plant quality
Market demand
Product uniqueness
Product inventory
Last year's prices
Demand factors
Population
Average population growth
Median household income
Urbanicity

Business characteristics

Business age

Region

Number permanent employees

Change in permanent employees

Selling characteristics

Total tradeshows attended

Repeat customers

Discount volume

Negotiated sales

Native plant sales

Wholesale sales

Home state sales

Exports

Other grower sales

Pre-committed sales

Total advertising

Impact of land on business ( $1-4$ scale $)$

Impact of market demand on business (1-4 scale)

Impact of labor on business (1-4 scale)

Impact of managerial experience on business (1-4 scale)

Impact of competition on business (1-4 scale)

Impact of environmental regulations on business (1-4 scale)

Importance of cost of production on pricing decisions (1-4 scale)

Importance of other grower prices on pricing decisions (1-4 scale)

Importance of plant quality on pricing decisions (1-4 scale)

Importance of market demand on pricing decisions ( $1-4$ scale)

Importance of product uniqueness on pricing decisions (1-4 scale)

Importance of product inventory on pricing decisions (1-4 scale)

Importance of last year's prices on pricing decisions (1-4 scale)

2003 population of county where business located Average growth/decline of population in county where business located from 2000 until 2003

2003 median household income of county where business located

Percent of county population that was white in 2003

Percentage of persons in the county living in the same household from 1995 until 2003

Whether county is defined as urban, where urban implies (county population/county land area) is greater than 1000 people/square miles

Age of business in years

Census region where business is located

Number of permanent employees

Change in number of permanent employees from 2002 to 2000

Number of tradeshows attended

Percentage of total sales coming from repeat customers

Offer discounts for volume purchases

Percentage of total sales coming from negotiated sales

Percentage of total sales coming from native plant sales

Percentage of total sales associated with wholesale sales

Percentage of total sales coming from home state

Percentage of total sales coming from exports

Percentage of total sales coming from selling plants from other growers

Percentage of total sales already contracted for sale before planting/potting

Dollars spent on all types of advertising during 2003

${ }^{2}$ The survey questions can be found in Brooker et al. (2005).

${ }^{y}$ The business influences were only used in the probit selection model, whereas the pricing influences were only used in the regression model.

"The 1-4 scale was used in which 1 = "not important" and 4 = "very important."

"The time period of 1995 until 2000 was used instead of until 2003 because the 2000-2003 values were not available.

selection bias, a statistically significant (from zero) IMR implies that sample selection bias would have occurred. If the model results in a significant IMR, then the coefficients for parameters appearing in both the first and second stages are not correct as noted by Saha et al. (1997) and must be adjusted (formula can be found in Saha et al., 1997).

Also of note is that interpreting the coefficients from the semilog model is straightfor- ward for continuous variables, but adjustments must be made for an appropriate interpretation of dummy variables. The continuous explanatory variables can be interpreted as follows: a one-unit change in the explanatory variable of interest results in a percent (value of coefficient) change in plant category sales. The elasticity associated with the continuous variables can be found by multiplying the coefficient of interest times the mean of the explanatory variable. To obtain an interpretation of the dummy variables (i.e., urbanicity, regions, and discount volume), the formula of Halvorsen and Palmquist (1980) is the commonly cited dummy variable transformation, whereby $\left[\exp \left(\mathrm{c}^{*}\right)-1\right]^{*} 100$ is used; however, as shown by Kennedy (1981), Eq. 7 provides a less biased representation of the true change. Therefore, we use the following formula given by Kennedy (1981):

$$
g^{*}=\left[\exp \left(c^{*}-\frac{1}{2} V\left(c^{*}\right)\right)-1\right] * 100
$$

where $\mathrm{c}^{*}$ is the coefficient estimate and $\mathrm{V}\left(\mathrm{c}^{*}\right)$ is the variance associated with each coefficient. After transforming the dummy variables, the interpretation is a change in the explanatory dummy variable from 0 to 1 implies a percent (as given by $\mathrm{g}^{*}$ ) in the dependent variable being evaluated.

\section{Results and Discussion}

Plant category gross sales. Examination of the results from the first-step probit models, Table 4, indicates that firms were correctly assigned into the right category between $68.8 \%$ and $81.3 \%$ for trees and roses, respectively. Table 5 gives the marginal effects obtained from the probit models and provides important insights into the factors driving plant category participation. A closer inspection of the business influences indicates that they do play a significant role for several of the plant categories. For instance, as the importance of labor as a factor that impacts the business increases, there is an increased probability of $6.73 \%$ and $9.21 \%$ associated with selling herbaceous perennials and bedding plants, respectively. This tends to make sense given herbaceous perennials and bedding plants can be labor-intensive plants. However, as the impact of managerial experience increases, the probability of selling trees decreases by $6.2 \%$ with a one-unit increase from the mean impact level. The reason for a decrease in the probability of selling trees given a higher impact of managerial experience is not as easily explained, thereby requiring further research to better understand this relationship.

With regard to demand factors, Table 5, we see that as the mean percentage of persons living in the same household increases one unit from the mean, there is a $1.08 \%$ increase in the probability of the firm selling trees. This finding makes intuitive sense given most benefits of trees are long term, so as more residents surrounding the firm stay in the same household over a period of time, then a firm is more likely to want to establish 
Table 3. Descriptive statistics of the explanatory variables delineated by plant category for data collected as part of the national nursery survey conducted by the Green Industry Research Consortium.

\begin{tabular}{|c|c|c|c|c|c|c|c|c|}
\hline & \multicolumn{8}{|c|}{ Firms that sell a product } \\
\hline & $\begin{array}{l}\text { Tree } \\
\text { sales }\end{array}$ & $\begin{array}{l}\text { Rose } \\
\text { sales }\end{array}$ & $\begin{array}{c}\text { Shrub }+ \\
\text { azalea sales }\end{array}$ & $\begin{array}{l}\text { Herbaceous } \\
\text { perennial } \\
\text { sales }\end{array}$ & $\begin{array}{l}\text { Bedding } \\
\text { plant } \\
\text { sales }\end{array}$ & $\begin{array}{l}\text { Foliage } \\
\text { sales }\end{array}$ & $\begin{array}{l}\text { Flowering } \\
\text { pot sales }\end{array}$ & $\begin{array}{l}\text { All } \\
\text { firms }\end{array}$ \\
\hline Cost of production & 3.3 & 3.5 & 3.3 & 3.6 & 3.5 & 3.6 & 3.5 & 3.3 \\
\hline Other grower prices & 2.8 & 2.7 & 2.8 & 2.9 & 2.5 & 2.6 & 2.6 & 2.8 \\
\hline Plant quality & 3.3 & 3.3 & 3.2 & 3.3 & 3.4 & 3.3 & 3.4 & 3.3 \\
\hline Market demand & 3.1 & 3.2 & 3.0 & 3.1 & 3.1 & 3.3 & 3.0 & 3.1 \\
\hline Product uniqueness & 2.8 & 3.2 & 2.8 & 3.0 & 3.0 & 3.1 & 3.1 & 2.8 \\
\hline Product inventory & 2.6 & 2.9 & 2.6 & 2.6 & 2.6 & 2.8 & 2.6 & 2.6 \\
\hline Last year's prices & 2.5 & 2.5 & 2.5 & 2.5 & 2.7 & 2.4 & 2.5 & 2.6 \\
\hline \multicolumn{9}{|l|}{ Demand factors } \\
\hline Population & 300,679 & 193,293 & 266,042 & 271,154 & 279,988 & 421,539 & 268,291 & 332,848 \\
\hline Average population growth (\%) & 3.4 & 3.4 & 3.3 & 3.2 & 2.5 & 4.7 & 2.3 & 3.4 \\
\hline Median household income (\$) & 42,627 & 44,679 & 43,013 & 43,895 & 42,617 & 42,630 & 42,045 & 42,395 \\
\hline Race (\% white) & 88.2 & 89.1 & 87.6 & 88.5 & 88.1 & 85.3 & 88.0 & 87.2 \\
\hline Same household (\% same household) & 55.9 & 56.9 & 55.9 & 55.1 & 56.0 & 53.8 & 57.6 & 55.1 \\
\hline Urbanicity ( $\%$ urban county) & 10.8 & 8.0 & 12.6 & 12.8 & 14.3 & 28.0 & 14.5 & 13.8 \\
\hline \multicolumn{9}{|l|}{ Business characteristics $^{y}$} \\
\hline Business age (years) & 25.6 & 31.2 & 28.6 & 26.8 & 23.3 & 24.0 & 21.5 & 22.4 \\
\hline Pacific $(\%)^{\mathrm{x}}$ & 7.9 & 4.0 & 6.2 & 12.8 & 9.9 & 4.0 & 10.9 & 12.3 \\
\hline Mountain (\%) & 6.8 & 8.0 & 6.9 & 6.4 & 6.6 & 4.0 & 3.6 & 4.7 \\
\hline West-North-Central (\%) & 10.7 & 20.0 & 10.4 & 12.8 & 6.6 & 6.0 & 9.1 & 6.4 \\
\hline East-North-Central (\%) & 18.1 & 12.0 & 16.7 & 19.3 & 9.9 & 8.0 & 5.5 & 16.1 \\
\hline Mid-Atlantic (\%) & 13.6 & 14.0 & 15.3 & 15.6 & 24.2 & 12.0 & 25.5 & 17.0 \\
\hline New England (\%) & 5.1 & 10.0 & 6.3 & 6.4 & 6.6 & 4.0 & 7.3 & 3.8 \\
\hline South Atlantic (\%) & 25.4 & 18.0 & 21.5 & 15.6 & 19.8 & 46.0 & 23.6 & 27.5 \\
\hline East-South-Central (\%) & 7.9 & 8.0 & 11.1 & 5.5 & 11.0 & 4.0 & 9.1 & 7.0 \\
\hline West-South-Central (\%) & 4.5 & 6.0 & 5.6 & 5.5 & 5.5 & 12.0 & 5.5 & 5.3 \\
\hline Change in permanent employees (\%) & 14.9 & 22.0 & 18.0 & 15.0 & 14.1 & 21.6 & 13.6 & 12.7 \\
\hline Number of permanent employees & 9.6 & 14.3 & 9.5 & 10.4 & 6.2 & 8.3 & 8.3 & 8.7 \\
\hline \multicolumn{9}{|l|}{ Selling characteristics } \\
\hline Total tradeshows attended & 1.5 & 1.7 & 1.5 & 1.4 & 0.9 & 1.6 & 1.2 & 1.3 \\
\hline Repeat customers (\%) & 72.7 & 73.2 & 73.2 & 73.0 & 71.8 & 76.0 & 74.7 & 72.8 \\
\hline Discount volume (\%) & 23.7 & 34.0 & 25.7 & 25.7 & 15.4 & 20.0 & 20.0 & 22.2 \\
\hline Negotiated sales $(\%)$ & 23.3 & 11.2 & 22.1 & 15.1 & 14.1 & 16.3 & 13.8 & 22.2 \\
\hline Native plant sales (\%) & 31.3 & 12.8 & 23.8 & 14.2 & 15.3 & 15.9 & 12.8 & 24.5 \\
\hline Wholesale sales (\%) & 57.4 & 32.8 & 55.5 & 42.8 & 30.1 & 55.0 & 37.2 & 57.5 \\
\hline Home state sales (\%) & 82.7 & 88.7 & 85.1 & 88.6 & 93.2 & 82.1 & 91.4 & 82.2 \\
\hline Exports (\%) & 0.5 & 0.1 & 0.1 & 0.4 & 0.1 & 0.4 & 0.2 & 0.8 \\
\hline Other grower sales (\%) & 19.0 & 32.1 & 22.3 & 23.7 & 22.2 & 27.9 & 23.8 & 14.6 \\
\hline Pre-committed sales $(\%)$ & 11.0 & 4.7 & 7.4 & 9.9 & 8.0 & 8.3 & 10.5 & 9.9 \\
\hline Total advertising & 24,912 & 61,153 & 33,084 & 38,869 & 25,626 & 36,520 & 32,292 & 19,895 \\
\hline
\end{tabular}

${ }^{2}$ Business impacts were included in the probit model only because it they were expected to have an effect on the decision to sell and not how much was sold. Business influences can be interpreted on a 1-4 scale with 1 having little effect on business decisions and 4 being very important to making business decisions. ${ }^{\mathrm{y}}$ The region variables along with discount volume and urbanicity are dummy variables.

${ }^{\mathrm{x} B a s e}$ category in subsequent analyses.

Table 4. Prediction accuracy of the probit models for each plant category model used to analyze data from the National Nursery Survey conducted by the Green Industry Research Consortium.

\begin{tabular}{lcccc}
\hline & $\begin{array}{c}\text { Percentage of } \\
\text { correct } \\
\text { predictions }(\%)\end{array}$ & $\begin{array}{c}\text { Sensitivity } \\
(\%)^{\mathrm{z}}\end{array}$ & $\begin{array}{c}\text { Specificity } \\
(\%)^{\mathrm{y}}\end{array}$ & $\begin{array}{c}\text { Cutoff } \\
\text { value }^{\mathrm{x}}\end{array}$ \\
Category & 68.8 & 67.8 & 69.9 & 51.8 \\
Trees & 81.3 & 85.7 & 80.6 & 14.6 \\
Roses & 70.0 & 69.0 & 70.8 & 42.1 \\
Shrubs + azaleas & 72.1 & 74.8 & 70.9 & 31.9 \\
Herbaceous perennials & 76.6 & 83.3 & 74.1 & 26.6 \\
Bedding plants & 74.2 & 77.1 & 73.7 & 14.6 \\
Foliage & 69.7 & 80.0 & 67.7 & 16.1 \\
Flowering pots & r. & &
\end{tabular}

${ }^{\mathrm{z}}$ Sensitivity is interpreted as the percentage of firms correctly classified as selling a specific plant category out of all firms selling the plant category (i.e., 67.8 of those selling trees were correctly classified as selling trees).

${ }^{y}$ Specificity is the percentage of firms correctly classified as not selling a specific plant category out of the total not selling the plant category (i.e., $69.9 \%$ of those not selling trees were correctly classified as not selling trees).

${ }^{\mathrm{x}}$ The conventional cutoff values of $50 \%$ were changed to more accurately reflect the frequencies displayed within the categories.

a presence in the tree market. On the other hand, if the county is considered to be urban, then there is a $24.3 \%$ decrease in the proba- bility of a firm selling trees. This also makes intuitive sense given major tree-producing regions of the country (e.g., middle Tennes- see and northern Ohio) tend to be located in rural counties, thereby if a nursery is in an urban county, it will be less likely to offer trees compared with a nursery located in a rural county. Furthermore, larger varieties of trees that require more space to grow may be less conducive to close spacing in an urban environment. Also of note is that as the percentage of residents staying in the same household increases by one unit from the mean, there is a $0.61 \%$ increase in the probability of selling potted flowering plants. The $0.61 \%$ change may seem small, but given a $2 \%$ or $3 \%$ increase in the mean, the percentage of residents remaining in the same household begins to become more and more important. For example, there is a $1.2 \%$ and $1.8 \%$ increase in the probability of selling bedding plants and potted flowering plants for a $2 \%$ and $3 \%$ increase from the mean, respectively. Evaluating the other plant categories finds several demand factors as 


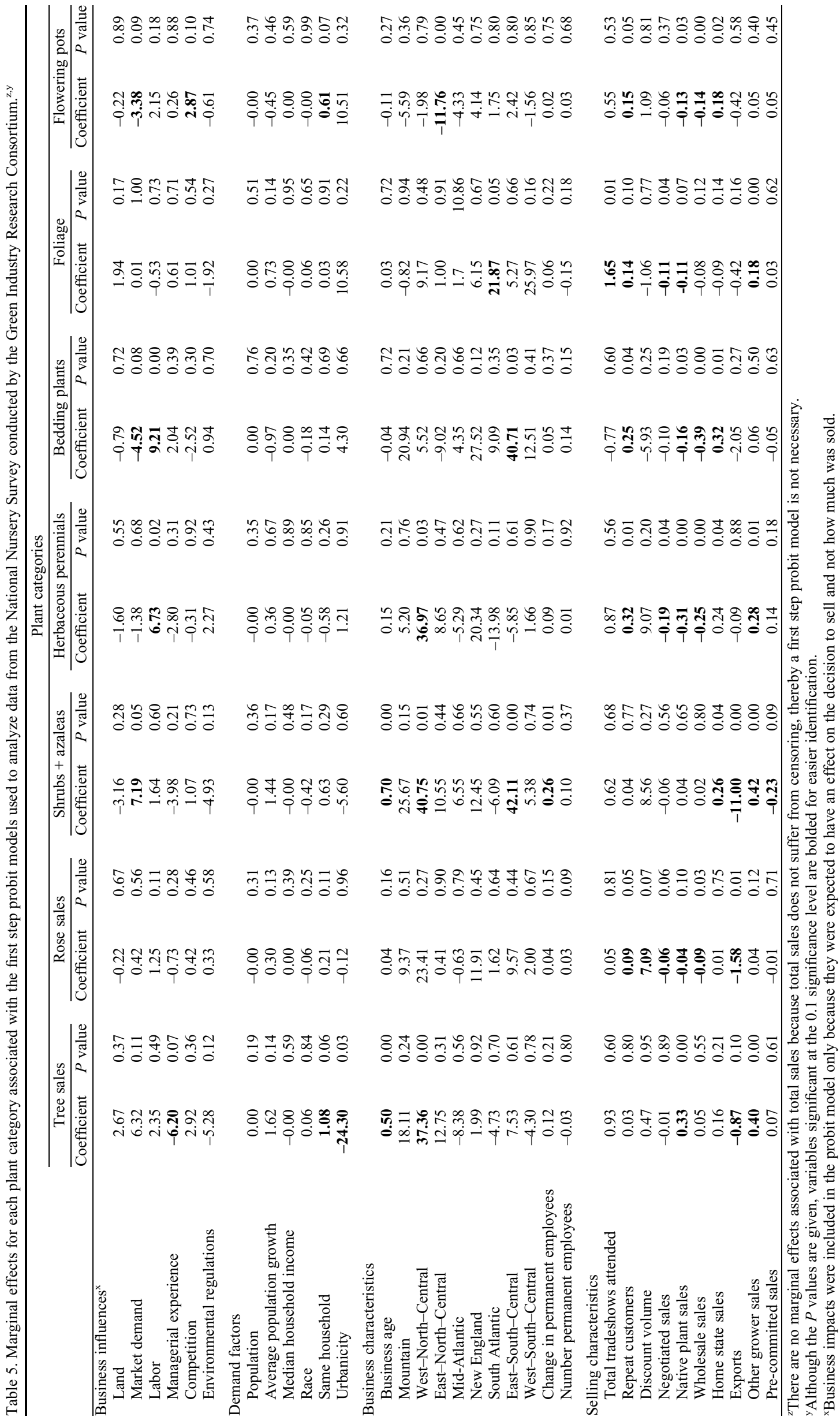




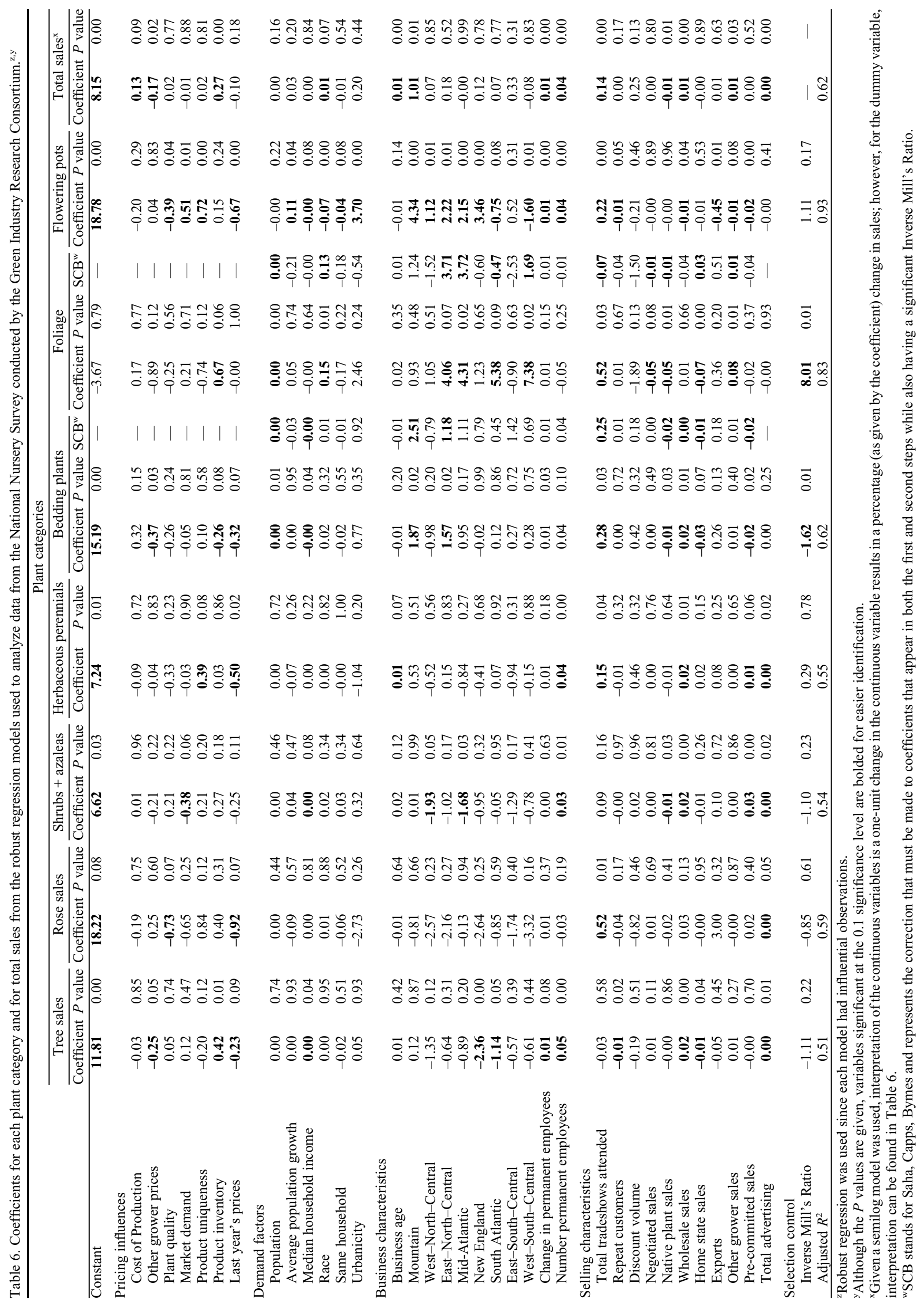


Table 7. Elasticities associated with results from each plant category and total sales derived from an analysis of data from the National Nursery Survey conducted by the Green Industry Research Consortium.

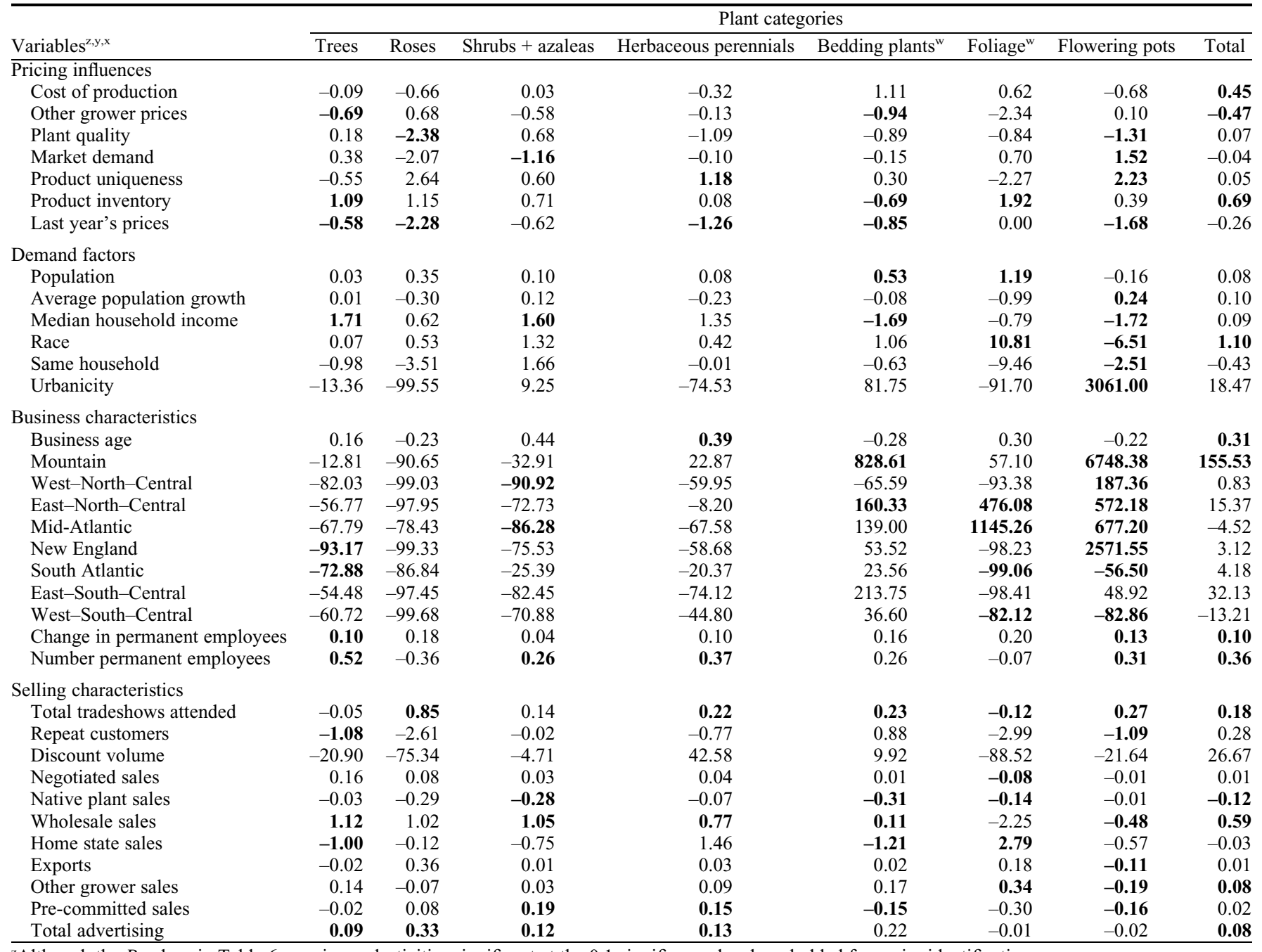

${ }^{2}$ Although the $P$ values in Table 6 are given, elasticities significant at the 0.1 significance level are bolded for easier identification.

'Elasticities for continuous variables were calculated by multiplying the coefficient (from Table 5) of the variable in question times the mean of the variable (as given in Table 4).

${ }^{x}$ Variable changes for dummy variables were calculated using the formula developed by Kennedy (1981).

"These elasticities, for continuous variables, were found by multiplying the variable means (Table 4) times the SCB-corrected coefficients (Table 5) when calculated by the normal coefficients when SCB coefficients were not calculated.

having $P$ values slightly above the 0.10 significance level cutoff, but readers can make their own determination if they are significant at higher significance levels.

Examining the effect of business characteristics on plant category participation reveals that region tends to be important for trees, shrubs/azaleas, and herbaceous perennials (see Table 5). A firm located in the West-North-Central or East-South-Central census region is $40.75 \%$ and $42.11 \%$ more likely to sell shrubs and azaleas than a firm in the pacific region, respectively. Business age and increasing number of permanent employees also play a role in the probability of selling shrubs/azaleas.

As expected, the selling characteristics of the firm play a large role in whether a firm sells a specific plant category. For instance, a firm offering volume discounts results in a $7.09 \%$ increase in the probability of selling roses, whereas increased sales through exporting results in a negative probability in selling trees, roses, shrubs, and azaleas. As the percent of sales associated with native plants increases, there is an increase in the probability of selling trees, whereas there is a negative effect on roses, herbaceous perennials, bedding plants, and foliage.

Turning to the regression results and elasticities for the plant categories, there are some interesting results regarding pricing tendencies (Tables 6 and 7). First, examination of pricing influences shows that as last year's pricing increases in importance on pricing decisions, then the firm experiences lower sales. This finding does not mean that a firm should stop using last year's prices as a piece of information to formulate a pricing strategy, but rather, a firm should use last year's prices as only a minor component of the determination of current prices. If we examine gross tree sales, we see that as last year's price increases in importance from the 2.5 mean (from Table 3) to 3.5 , gross sales decrease by $0.23 \%$. Roses, herbaceous pe- rennials, bedding plants, and flowering pots also experience decreases in gross sales as last year's prices become more important in pricing decisions. On the other hand, as product inventory becomes more important in pricing decisions, gross sales of trees and foliage increase by $0.42 \%$ and $0.67 \%$, respectively. The elasticities in Table 7 indicate that a $1 \%$ increase in product importance results in increases of $1.09 \%$ and $1.92 \%$ in gross tree and foliage sales, respectively.

Demand factors also play a role in affecting plant category sales with income, population, and race tending to be the only significant variables, except for the potted flowering plants category. Evaluating the elasticities with respect to income, we see that as the median income rises by $1 \%$, there is a corresponding increase in gross sales of $1.71 \%$ and $1.60 \%$ for trees and roses, respectively; however, there is a decrease of $1.69 \%$ and $1.72 \%$ for potted flowering plants. As the proportion of whites within the county 
increases, there is a $10.81 \%$ increase in foliage sales but a $6.51 \%$ decrease in potted flowering plants. Furthermore, if a county can be described as urban, there is a $3061 \%$ increase in sales associated with the flowering potted plant category.

Examining the effects of business characteristics on sales indicates that, as expected, region plays a significant role in the sales associated with certain plant categories. Of specific interest is the large percentage increases in flowering potted plant sales associated with firms in regions other than the Pacific region.

Selling characteristics are also an important indicator of sales. Firms with $1 \%$ increased trade show attendance results in increased gross sales for all plant categories except trees and shrubs and azaleas, which is insignificant (Table 7). Also of note is that as the percentage of sales associated with wholesale sales increases (as compared with direct retail sales), most plant categories experience significant increases in gross sales, except for roses, foliage, and potted flowering plants. Increasing the percentage contracted through wholesale channels results in increased sales ranging from $0.11 \%$ to $1.12 \%$ for bedding plants and trees, respectively. However, potted flowering plants experience a $0.48 \%$ decrease in sales with a $1 \%$ increase in wholesale selling.

Furthermore, as the percentage of sales associated with native plants increases by $1 \%$, there is a decrease in gross sales associated with shrubs/azaleas, bedding plants, foliage, and potted flowering plants. The decrease associated with increasing native plant sales could be caused by sales moving elsewhere as a result of a lack of variety (of nonnative species) or because of lower prices associated with native plants, thereby leading to larger quantities sold but at lower prices or perhaps firms that sell native plants (and self-report that way) are smaller firms overall, so they are likely to have lower overall gross sales.

A closer look at total gross sales indicates that several pricing influences affect sales. For instance, as cost of production and product inventory increase in their importance on pricing by one unit, there is an increase in total gross sales of $0.13 \%$ and $0.27 \%$, respectively; however, as other grower prices increase in importance, total gross sales decrease by $0.17 \%$. Instituting a $1 \%$ change in cost of production and product inventory importance shows a $0.45 \%$ and $0.69 \%$ increase in sales, respectively, versus a $0.47 \%$ decrease associated with other grower prices. From a grower/retailer prospective, we see that how prices are determined can potentially play a large role in sales, thereby grower/retailers need to be aware of how their reliance on outside criteria in their pricing strategies can have an impact on their bottom line.

Demand factors and business characteristics seem to play a more limited role in total gross sales. Race, business age, Mountain census region, changes in permanent employees, and total employees all result in increased total gross sales.

As expected, selling characteristics play a large role in total gross sales. Increasing the number of trade shows attended by $1 \%$ results in a $0.18 \%$ increase in sales, whereas increased wholesale sales result in a $0.59 \%$ increase in sales. However, increases in native plant sales result in a $0.12 \%$ decrease in total sales overall.

\section{Conclusions}

Nursery and greenhouse firms are facing increased pressures from the changing face of the green industry. Sound decision-making and a strategic mindset are key to a firm's longevity within this hypercompetitive marketplace. However, little is known about how a firm's decision-making and subsequent strategic actions affect sales. Through this research, we have taken an exploratory look to see the effects of pricing influences, demand factors, business characteristics, and selling characteristics on not only sales, but also their effect on whether a firm participates in a specific plant category market.

As expected, our results show that region is a primary driver of whether a firm makes the decision to sell a particular plant category. However, by controlling for business characteristics (i.e., region) and business influences, selling characteristics such as negotiated sales, native plant sales, and sales for other growers are also important in making the decision to participate in a plant category market.

In regard to sales, our results show that certain factors affecting pricing decisions play a critical role in both plant category sales and total sales. Furthermore, demand and business characteristics play a role as well, but not as big a role as selling characteristics. Of note is that increasing the percent of sales through wholesale channels (of most plant categories and overall) results in increased sales.

By understanding the nursery and greenhouse industry environment and how decisions affect not only overall sales, but category sales as well, firms can implement strategies that capitalize on factors that have the potential to generate increased sales. In this regard, this research serves as an impor- tant first step by allowing firms access to more information so as to make better managerial decisions.

\section{Literature Cited}

Andrade, M.A. and R.A. Hinson. 2009. Making the choice between rewholesalers and other nursery market channels. HortScience 44:372376.

Behe, B.K., J.H. Dennis, C.R. Hall, A.W. Hodges, and R.G. Brumfield. 2008. Regional marketing practices in U.S. nursery production. HortScience 43:2070-2075.

Brooker, J., D. Eastwood, C. Hall, K. Morris, A. Hodges, and J. Haydu. 2005. Trade flows and marketing practices within the United States nursery industry: 2003. Southern Coop. Bul. 404, Univ. of Tenn. Ag. Exp. Sta.

Byrne, P.J., O. Capps Jr., and A. Saha. 1998. Analysis of quick-serve, mid-scale, and upscale food away from home expenditures. Intl. Food and Agribusiness Mgt. Rev. 1:51-72.

Campbell, B.L., C.R. Hall, and B.F. Combs. 2009. Regional structural change in production and marketing practices for the nursery and greenhouse industry: 1989-2004. J. Environ. Hort. 27:139-144.

Davidson, R. and J.G. MacKinnon. 1993. Estimation and inference in econometrics. Oxford University Press, New York, NY.

Dennis, J.H. and B.K. Behe. 2007. Evaluating the role of ethnicity on gardening purchases and satisfaction. HortScience 42:262-266.

Greene, W.H. 2003. Econometric analysis. 5th Ed. Prentice Hall, Upper Saddle River, NJ.

Hall, C.R. 2002. Measuring and assessing the image of retail garden centers. Bul. AE02-51, Univ. of Tenn. Ag. Exp. Sta.

Hall, C.R. 2007. How to survive a maturing nursery market. Nursery Mgt. Production March:5357.

Halvorsen, R. and R. Palmquist. 1980. The interpretation of dummy variables in semilogarithmic equations. Amer. Econ. Rev. 70:474475.

Heckman, J. 1979. Sample selection bias as specification error. Econometrica 47:153-161.

Hodges, A.W., C.R. Hall, B.K. Behe, and J.H. Dennis. 2008. Regional analysis of production practices and technology use in the U.S. nursery industry. HortScience 43:1807-1812.

Jerardo, A. 2007. Floriculture and nursery crops yearbook 2007 (Spreadsheet Files)—TableA-1. xls. USDA-Economic Research Service, FLO2007, 1 June 2009. <http://usda.mannlib.cornell. edu/MannUsda/viewDocumentInfo.do?document $\mathrm{ID}=1448>$.

Kennedy, P.E. 1981. Estimation with correctly interpreted dummy variables in semilogarithmic equations. Amer. Econ. Rev. 71:801.

Saha, A., O. Capps, and P.J. Byrne. 1997. Calculating marginal effects in dichotomous-continuous models. Appl. Econ. Lett. 4:181-185.

Yue, C. and B.K. Behe. 2008. Estimating U.S. consumers' choice of floral retail outlets. HortScience 43:764-769. 